\title{
PENGGUNAAN FORMULA CAIR Trichoderma harzianum T10 BERBAHAN TEPUNG JAGUNG TERHADAP REBAH SEMAI (Pythium sp.) BIBIT MENTIMUN
}

\author{
Liquid Formula Use of Trichoderma harzianum T10 based on Corn Starch Towards \\ Damping-Off (Pythium sp.) on Cucumber Seedlings
}

\author{
Wiwit Ningtias, Endang Mugiastuti, Ruth Feti Rahayuniati, Loekas Soesanto* \\ Fakultas Pertanian, Universitas Jenderal Soedirman \\ Jl. Dr. Soeparno 73, Purwokerto 53123 \\ *Email korespondensi: lukassusanto26@gmail.com
}

Diterima 8 September 2020/Disetujui 21 Oktober 2020

\begin{abstract}
ABSTRAK
Penelitian bertujuan untuk: 1) mengetahui konsentrasi tepung jagung yang tepat untuk medium cair Trichoderma harzianum T10, 2) mengetahui pengaruh aplikasi T. harzianum T10 dalam berbagai konsentrasi medium cair tepung jagung terhadap penekanan penyakit rebah semai dan pertumbuhan bibit mentimun. Penelitian dilaksanakan di Laboratorium Perlindungan Tanaman dan di lahan Fakultas Pertanian, Universitas Jenderal Soedirman pada bulan September 2017 sampai Januari 2018. Pengujian in vitro menggunakan Rancangan Acak Lengkap dengan lima perlakuan dan lima ulangan, meliputi perlakuan formula cair medium Potato Dextrose Broth (PDB), formula cair tepung jagung konsentrasi 5, 10, 15 dan 20 g/L. Pengujian in planta menggunakan Rancangan Acak Kelompok dengan 6 perlakuan dan 5 ulangan, membandingkan kontrol dengan tanaman yang diberi perlakuan T. harzianum T10 pada masing-masing formula cair konsentrasi tepung jagung. Variabel yang diamati meliputi kepadatan konidium, masa inkubasi, kejadian penyakit, area under disease progress curve (AUDPC), potensi tumbuh maksimum, daya kecambah, tinggi tanaman, panjang akar, bobot segar akar dan bobot segar tajuk. Hasil penelitian menunjukkan bahwa kepadatan konidium $T$. harzianum T10 tertinggi pada formula medium cair tepung jagung konsentrasi $20 \mathrm{~g} / \mathrm{L}$ sebesar $3,67 \times 10^{6}$ konidium/mL, tetapi belum mampu menyamai medium PDB. Aplikasi T. harzianum T10 yang efektif menekan penyakit rebah semai adalah perlakuan $T$. harzianum T10 dalam formula cair tepung jagung konsentrasi $15 \mathrm{~g} / \mathrm{L}$, yaitu mampu menekan kejadian penyakit $71,43 \%$ dan menunda masa inkubasi 35,83\%. Aplikasi T. harzianum T10 selain konsentrasi 15 $\mathrm{g} / \mathrm{L}$ belum berpengaruh terhadap variabel yang diamati dan diukur.
\end{abstract}

Kata Kunci: Mentimun, metabolit sekunder, T. harzianum T10, Pythium sp., tepung jagung

\section{ABSTRACT}

This research aimed to: 1) determine the correct concentration of corn starch for liquid medium Trichoderma harzianum T10, 2) determine the effect of application T. harzianum T10 in various concentration of corn starch liquid medium to pressing damping-off disease, and cucumber seed growth. The research was conducted at the Plant Protection Laboratory and land of Agriculture Faculty, Jenderal Soedirman University, from September 2017 to January 2018. In vitro test was used Rendomized Completely Design with 5 treatments and 5 replications, including the Potato Dextrose Broth (PDB), formula of corn starch concentrate $5,10,15$, and $20 \mathrm{~g} / \mathrm{L}$. In planta test was used Rendomized Block Design with 6 treatments and 5 replications, compared control with plants treated with T. harzianum T10 in each liquid formula of corn starch concentration. Variables observed were conidium density, incubation 
period, disease incidence, area under disease progress curve (AUDPC), maximum growth potential, germination, plant height, root length, fresh root weight and fresh crown weight. Result of the research showed that the highest T. harzianum T10 conidium density in liquid corn starch medium contentration of $20 \mathrm{~g} / \mathrm{L}$ was $3,67 \times 10^{6}$ conidium $/ \mathrm{mL}$, but not yet able to match the medium PDB. The effective application of T. harzianum T10 to pressing dampingoff disease is the treatment of T. harzianum T10 in a formula corn starch concentration of 15 $g / L$, by pressing incidence disease of $71,43 \%$ and delaying the incubation period of $35,83 \%$. The application of T. harzianum T10 in addition concentration of $15 \mathrm{~g} / \mathrm{L}$ has not affected the variables observed and measured.

Key words: Cucumber, secondary metabolites, T. harzianum T10, Pythium sp., corn starch

\section{PENDAHULUAN}

Mentimun (Cucumis sativus L.) merupakan tanaman sayuran penting (HinaSaeed 2018). Buah mentimun dapat dikonsumsi dalam bentuk segar, sebagai pencuci mulut, bahan kosmetik dan dapat dijadikan bahan obat. Upaya meningkatkan produksi tanaman mentimun sering dihadapkan pada gangguan organisme pengganggu tanaman. Salah satu penyakit utama pada tanaman mentimun adalah rebah semai (damping-off) yang disebabkan Pythium sp. (Salman et al. 2013). Infeksi Pythium sp. sebelum tanaman muncul dari medium tanam, menyebabkan bibit dan bibit muda membusuk sebelum muncul. Sementara, setelah tanaman muncul ke tanah mengakibatkan rebah semai (Sutton et al. 2006).

Kerusakan tanaman akibat patogen umumnya diatasi dengan pestisida sintetis. Penggunaan pestisida sintetis menimbulkan potensi bahaya bagi kesehatan manusia dan lingkungan (Jansch et al. 2006; Al-Zaidi et al. 2011). Salah satu upaya untuk mengganti penggunaan pestisida sintetik, yaitu dengan pengendalian hayati. Menurut Lahre et al. (2012), pengendalian secara hayati mempunyai banyak keuntungan dibandingkan cara pengendalian lain.

Trichoderma sp. dipertimbangkan sebagai agensia pengendali hayati yang mapan dan mudah didapatkan sebagai alternatif pengendali patogen tanaman
(Munir et al. 2013; Ghazanfar et al. 2018). Penggunaan Trichoderma spdalam jangka pendek berpengaruh mengendalikan penyakit dan meningkatan pertumbuhan tanaman. Dalam jangka panjang Trichoderma sp, mampu menurunkan inokulum patogen jamur di lapangan (Tran 2010).

Kinerja mikroba cepat menurun bila terkena sinar matahari secara langsung saat diaplikasikan di lahan (Hockberger 2000) dan oleh senyawa kimia (Muturi et al. 2017), sehingga membatasi kemampuannya. Pengembangan antagonis potensial menghadapi beberapa kesulitan, diantaranya ukuran populasi, viabilitas dan keefektifannya. Mikroba dapat diformula dalam berbagai bahan pembawa, yang harus memberikan kondisi yang menguntungkan untuk mikroba (Panahian et al. 2012). Salah satu alternatif substrat yang dapat digunakan yaitu tepung jagung karena mengandung karbohidrat, protein, dan lemak yang cukup tinggi. Suarni dan Firmansyah (2005) menyatakan kandungan gizi tepung jagung adalah air $10,09 \%$, abu $2,01 \%$, protein $8,78 \%$, lemak $4,92 \%$, karbohidrat $74,20 \%$, dan 3,12\% serat kasar. Penelitian ini bertujuan untuk mengetahui konsentrasi tepung jagung yang tepat terhadap pertumbuhan dan produksi metabolit sekunder $T$. harzianum T10, mengetahui pengaruhnya terhadap penekanan penyakit rebah semai dan terhadap pertumbuhan bibit mentimun. 


\section{METODE PENELITIAN}

\section{Tempat dan Waktu}

Penelitian ini dilaksanakan pada bulan September 2017 sampai Januari 2018 dalam dua tahap, yaitu secara in vitro di Laboratorium Perlindungan Tanaman dan in planta di lahan Fakultas Pertanian, Universitas Jenderal Soedirman.

\section{Penyiapan isolat T. harzianum T10}

Trichoderma harzianum T10 diperbanyak dalam medium PDA, selanjutnya diperbanyak ke medium padat jagung pecah (Heydari, Pessarakli 2010; Gusnawaty et al. 2014). Jagung yang telah ditumbuhi jamur ditimbang $10 \mathrm{~g}$ dan diencerkan dalam $250 \mathrm{~mL}$ air steril. Selanjutnya, T. harzianum T10 dihitung kepadatan konidiumnya menggunakan haemocytometer (Akagi et al. 2015). Kepadatan konidium diencerkan kembali sampai $10^{6}$ konidium $/ \mathrm{mL}$.

\section{Pembuatan metabolit sekunder}

Medium cair dibuat lima perlakuan. Perlakuan kontrol (medium PDB), perlakuan formula cair tepung jagung konsentrasi 5, 10, 15 dan $20 \mathrm{~g} / \mathrm{L}$ dengan mencampur masing-masing konsentrasi tepung jagung ditambah $10 \mathrm{~g} / \mathrm{L}$ dekstrosa. Setiap medium dibuat $100 \mathrm{~mL}$ dan ditambahkan $1 \mathrm{~mL}$ T. harzianum T10 dengan kepadatan $10^{6}$ konidium $/ \mathrm{mL}$. Selanjutnya setiap perlakuan di-shaker selama 7 hari dengan kecepatan $150 \mathrm{rpm}$ (Han et al. 2012) dan kepadatan konidiumnya dihitung kembali dengan haemocytometer. Setiap perlakuan diencerkan kembali sampai kepadatan $10^{6}$ konidium $/ \mathrm{mL}$.

\section{Penyiapan Pythium sp.}

Isolasi patogen dilakukan dengan memotong bagian yang terinfeksi patogen (bibit yang terkena rebah semai) dengan ukuran 1x1 cm. Potongan bagian tanaman dicelupkan dengan alkohol $70 \%$ selama 2 menit, kemudian dibilas dengan air steril sebanyak 3 kali. Potongan bibit kemudian diletakkan pada medium PDA sehingga tumbuh koloni jamur (Suryanti et al. 2013). Koloni selanjutnya diidentifikasi berdasarkan pustaka (Patil, Rathore 2018). Koloni selanjutnya diuji postulat Koch (Byrd, Segre 2016).

\section{Inokulasi Pythium sp. dan Aplikasi Metabolit Sekunder}

Inokulasi Pythium sp. dilakukan dengan memasukkan 1 bor gabus biakan Pythium sp. dengan diameter $1 \mathrm{~cm}$ pada lubang tanam dan ditutup tipis dengan tanah. Selanjutnya, benih mentimun (varietas Mercy F1) diletakkan di atasnya dan ditutup tipis tanah. Aplikasi dilakukan dengan menambahkan $10 \mathrm{~mL}$ metabolit sekunder $T$. harzianum T10 pada masingmasing perlakuan (hasil dari kepadatan $10^{6}$ konidium/mL) ke dalam lubang tanam dan ditutup tanah kembali.

\section{Rancangan Percobaan}

Pengujian in vitro menggunakan Rancangan Acak Lengkap dengan 5 perlakuan dan 5 ulangan, meliputi perlakuan formula cair medium Potato Dextrose Broth (PDB), metabolit sekunder berdasar tepung jagung konsentrasi 5, 10, 15 dan $20 \mathrm{~g} / \mathrm{L}$. Pengujian in planta menggunakan Rancangan Acak Kelompok dengan 6 perlakuan dan 5 ulangan. Perlakuan terdiri atas kontrol, metabolit sekunder T. harzianum T10 berdasar PDB, dan metabolit sekunder T. harzianum T10 berdasar tepung jagung konsentrasi 5, 10, 15 , dan $20 \mathrm{~g} / \mathrm{L}$.

\section{Variabel dan Pengukuran}

Variabel yang diamati dalam penelitian ini, yaitu kepadatan konidium (Akagi et al. 2015), masa inkubasi, kejadian penyakit dengan rumus $\mathrm{KP}=(\mathrm{n} / \mathrm{N}) \times 100 \%$, dengan: $\mathrm{KP}$ (kejadian penyakit), $\mathrm{n}$ (jumlah tanaman terserang), dan $\mathrm{N}$ (jumlah total tanaman) (Noordzij et al. 2010), AUDPC dengan rumus: 


$$
\operatorname{AUDPC} \sum_{i=0}^{n-1}\left(\frac{\mathrm{Yi}+\mathrm{Yi}+1}{2}\right) \cdot\left(\mathrm{t}_{i+1}-t_{i}\right)
$$

Keterangan: $\quad$ AUDPC: Kurva perkembangan penyakit, $\mathrm{Y}=$ keparahan penyakit pada waktu $\mathrm{t}, \mathrm{i}=$ jumlah hari setelah tanam, waktu oengamatan ke-i, $\mathrm{n}=$ jumlah total pengukuran (Ling et al. 2017), potensi tumbuh maksimum, daya kecambah, tinggi tanaman, panjang akar, bobot akar, dan bobot tajuk.

\section{Analisis Data}

Data kuantitatif (percobaan in planta) dianalisis keragaman (uji F) pada taraf kesalahan 5\%. Apabila terdapat perbedaan nyata dan sangat nyata, dilanjutkan DMRT (Duncan's Multiple Range Test) pada taraf kesalahan $5 \%$.

\section{HASIL DAN PEMBAHASAN}

\section{Kepadatan Konidium}

Hasil tertinggi kepadatan konidium $T$. harzianum T10 ditunjukkan pada konsentrasi tepung jagung $20 \mathrm{~g} / \mathrm{L}$, selanjutnya konsentrasi 15, 10 dan $5 \mathrm{~g} / \mathrm{L}$.
Perlakuan tepung jagung belum mampu meningkatkan kepadatan konidum dibandingkan kontrol, dengan perbandingan $\mathrm{K} 4$ dan PDB yaitu $1: 6,5$ (Gambar 1). Meskipun demikian, medium cair tepung jagung berpotensi sebagai alternatif medium pertumbuhan $T$. harzianum T10. Menurut Tran (2010), jagung sebagai salah satu medium yang telah terbukti mampu memacu pertumbuhan Trichoderma sp.

Perbedaan jumlah kondium Trichoderma sp. yang dibentuk sangat ditentukan oleh kandungan nutrisi medium (Mishra, Khan 2015). Borin et al. (2015), menyarankan bahwa pertumbuhan $T$. reesei dan Aspergillus niger sangat bergantung pada ketersediaan karbohidrat dan digunakan sebagai sumber energi untuk tumbuh. Hal tersebut sesuai, yaitu semakin tinggi konsentrasi tepung jagung memberikan hasil kepadatan konidium yang lebih besar. Medium PDB memberikan hasil yang lebih tinggi, diduga karena kandungan karbohidrat dalam $100 \mathrm{~g}$, tepung kentang (85,6 g) lebih tinggi dibandingkan tepung jagung $(73,7 \mathrm{~g})$ (Murtiningsih dan Suyanti 2011).

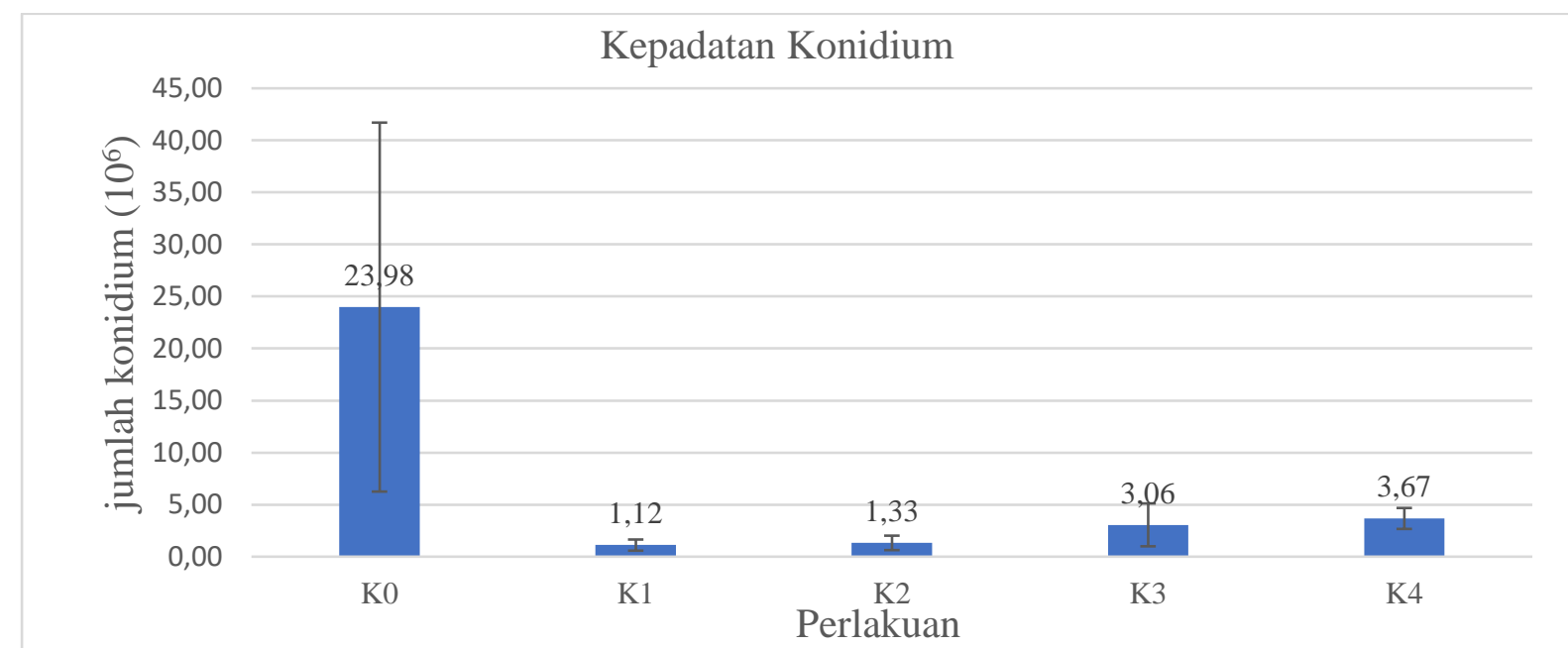

Gambar 1. Kepadatan konidium T. harzianum T10. Keterangan: $\mathrm{K} 0=T$. harzianum $\mathrm{T} 10$ medium PDB (kontrol), $\mathrm{K} 1=T$. harzianum $\mathrm{T} 10$ medium tepung jagung $5 \mathrm{~g} / \mathrm{L}, \mathrm{K} 2=T$. harzianum $\mathrm{T} 10$ medium tepung jagung $10 \mathrm{~g} / \mathrm{L}, \mathrm{K} 3=T$. harzianum $\mathrm{T} 10$ medium tepung jagung $15 \mathrm{~g} / \mathrm{L}$, dan $\mathrm{K} 4=T$. harzianum medium tepung jagung $20 \mathrm{~g} / \mathrm{L}$. 
Penelitian Saha et al. (2008), menunjukkan medium PDB memberikan hasil terbaik dibandingkan medium alternatif, karena PDB memiliki formula yang sederhana dan mampu mendukung pertumbuhan jamur. Tepung jagung mengandung 25-30\% amilosa dan 70-75\% amilopektin. Amilopektin merupakan polisakarida terbesar (Aini 2013), sehingga jamur membutuhkan waktu lebih lama untuk menguraikan menjadi komponen sederhana yang dapat diserap sel untuk sintesis sel dan energi.

Tabel 1. Kejadian penyakit, masa inkubasi dan AUDPC pada berbagai konsentrasi medium cair

\begin{tabular}{ccll}
\hline Perlakuan & $\begin{array}{c}\text { Kejadian Penyakit } \\
(\%)\end{array}$ & $\begin{array}{c}\text { Masa Inkubasi (hari } \\
\text { setelah inokulasi) }\end{array}$ & AUDPC (\%-hari) \\
\hline Kontrol & $70,00^{\mathrm{b}}$ & $12,70^{\mathrm{a}}$ & 700 \\
PDB & $16,60^{\mathrm{a}}$ & $17,24^{\mathrm{b}}$ & 126 \\
Tp jagung 5 g/L & $28,20^{\mathrm{ab}}$ & $17,02^{\mathrm{ab}}$ & 225,4 \\
Tp jagung 10 g/l & $30,00^{\mathrm{ab}}$ & $15,45^{\mathrm{ab}}$ & 335 \\
Tp jagung 15 g/l & $20,00^{\mathrm{a}}$ & $17,25^{\mathrm{b}}$ & 195 \\
Tp jagung 20 g/l & $33,34^{\mathrm{ab}}$ & $15,43^{\mathrm{ab}}$ & 455,02 \\
\hline
\end{tabular}

Keterangan: Angka yang diikuti huruf sama pada kolom sama menunjukkan tidak berbeda nyata pada BNJ dengan taraf kesalahan 5\%. Data kejadian penyakit ditransformasi ke $\arcsin \sqrt{\mathrm{x}+0,5}$ dan data masa inkubasi ditransformasi ke $\sqrt{\mathrm{x}}$

\section{Kejadian penyakit}

Aplikasi metabolit sekunder $T$. harzianum T10 pada formula cair tepung jagung konsentrasi $15 \mathrm{~g} / \mathrm{L}$ dan medium PDB memberikan hasil terbaik, meskipun semua perlakuan tidak berbeda nyata (Tabel 1). Perlakuan konsentrasi $15 \mathrm{~g} / \mathrm{L}$, mampu menurunkan kejadian penyakitnya $71,43 \%$ dan medium PDB mampu menurunkan 76,28\% dibandingkan kontrol. Perlakuan metabolit sekunder T. harzianum T10 konsentrasi 5, 10 dan $20 \mathrm{~g} / \mathrm{L}$ menunjukkan hasil tidak berbeda nyata dibandingkan kontrol. Meskipun demikian, ke-3 perlakuan tersebut mampu menunda kejadian penyakit masing-masing sebesar $59,71,57,14$ dan 52,37\%.

Perlakuan metabolit sekunder konsentrasi $20 \mathrm{~g} / \mathrm{L}$ menunjukkan kejadian penyakit yang lebih besar dibandingkan konsentrasi $15 \mathrm{~g} / \mathrm{L}$. Hal tersebut diduga saat aplikasi, formula cair pada konsentrasi 20 $\mathrm{g} / \mathrm{L}$ masih memiliki nutrisi yang cukup melimpah. Nutrisi tersebut dimanfaatkan oleh T. harzianum T10 dan Pythium sp. Jamur dapat merombak karbohidrat dan protein menjadi energi untuk membentuk spora (Manurung et al. 2012). Jumlah spora
Pythium sp. diduga bertambah, sehingga kejadian penyakit yang mampu ditekan lebih kecil. Penelitian Hardianti et al. (2014), menunjukkan adanya kompetisi bahan makanan antara patogen jamur $F$. oxysporum dengan $T$. harzianum di dalam tanah.

Mekanisme antagonis T. harzianum salah satunya dengan metabolit sekunder. Metabolit sekunder T. harzianum mengandung senyawa lengkap seperti antibiotika, enzim, hormon, dan toksin yang dapat terangkut oleh air dan hara, sehingga dapat mencapai jaringan pembuluh (Vinale et al. 2014). Antibiotika dan enzim tersebut berperan penting di dalam pengendalian penyakit tanaman.

\section{Masa inkubasi}

Masa inkubasi patogen Pythium sp. tercepat pada perlakuan kontrol. Perlakuan metabolit sekunder medium PDB dan konsentrasi tepung jagung $15 \mathrm{~g} / \mathrm{L}$ memberikan hasil yang nyata dapat menunda masa inkubasi penyakit rebah semai (Tabel 1). Perlakuan metabolit sekunder T. harzianum T10 konsentrasi tepung jagung 5, 10 dan $20 \mathrm{~g} / \mathrm{L}$ 
memberikan hasil tidak nyata, artinya belum mampu menunda masa inkubasi dari patogen Pythium sp. Hal tersebut sebanding dengan besaran kejadian penyakit (Tabel $1)$.

Perlakuan kontrol menunjukkan masa inkubasi penyakitnya 12,7 hari setelah inokulasi, yang lebih cepat dibandingkan masa inkubasi pada perlakuan. Perlakuan metabolit sekunder $T$. harzianum $\mathrm{T} 10$ medium PDB mampu menunda masa inkubasi $35,75 \%$; sedangkan metabolit sekunder T. harzianum T10 formula tepung jagung konsentrasi 5, 10, 15 dan $20 \mathrm{~g} / \mathrm{L}$ masing-masing mampu menunda 34,02, $21,65,35,83$ dan $21,50 \%$ dibandingkan kontrol.

Mekanisme metabolit sekunder dalam menghambat perkembangan patogen melalui denaturasi protein. Senyawa aktif pada metabolit sekunder mampu memecah ikatan disulfida yang menghubungkan antar-polipeptida protein dinding sel dan membran sel. Denaturasi protein struktur pada dinding sel akan menyebabkan sel menjadi lebih rentan, sedangkan pada membran sel patogen akan menyebabkan kehilangan sifat permeabilitas, sehingga tidak dapat menyeleksi zat yang keluar masuk sel. Keadaan ini menyebabkan senyawa metabolit sekunder dapat masuk ke dalam sel, sehingga menyebabkan sel menjadi lisis dan mati (Ekowati et al. 2009).

\section{AUDPC}

Berdasarkan nilai AUDPC, kontrol menunjukkan nilai 700\%-hari (Tabel 1). Perlakuan metabolit sekunder T. harzianum medium PDB mampu menurunkan nilai AUDPC sebesar $82 \%$, sedangkan metabolit sekunder T. harzianum T10 medium tepung jagung konsentrasi 5, 10, 15 dan $20 \mathrm{~g} / \mathrm{L}$ menurunkan masing-masing sebesar 67,8; 52,$14 ; 72,14 \%$ dan $35 \%$ dibandingkan kontrol (Gambar 1). Hal tersebut selaras dengan kejadian penyakit, yaitu mampu menurunkan kejadian penyakit yang ditunjukkan dengan kecilnya nilai AUDPC.

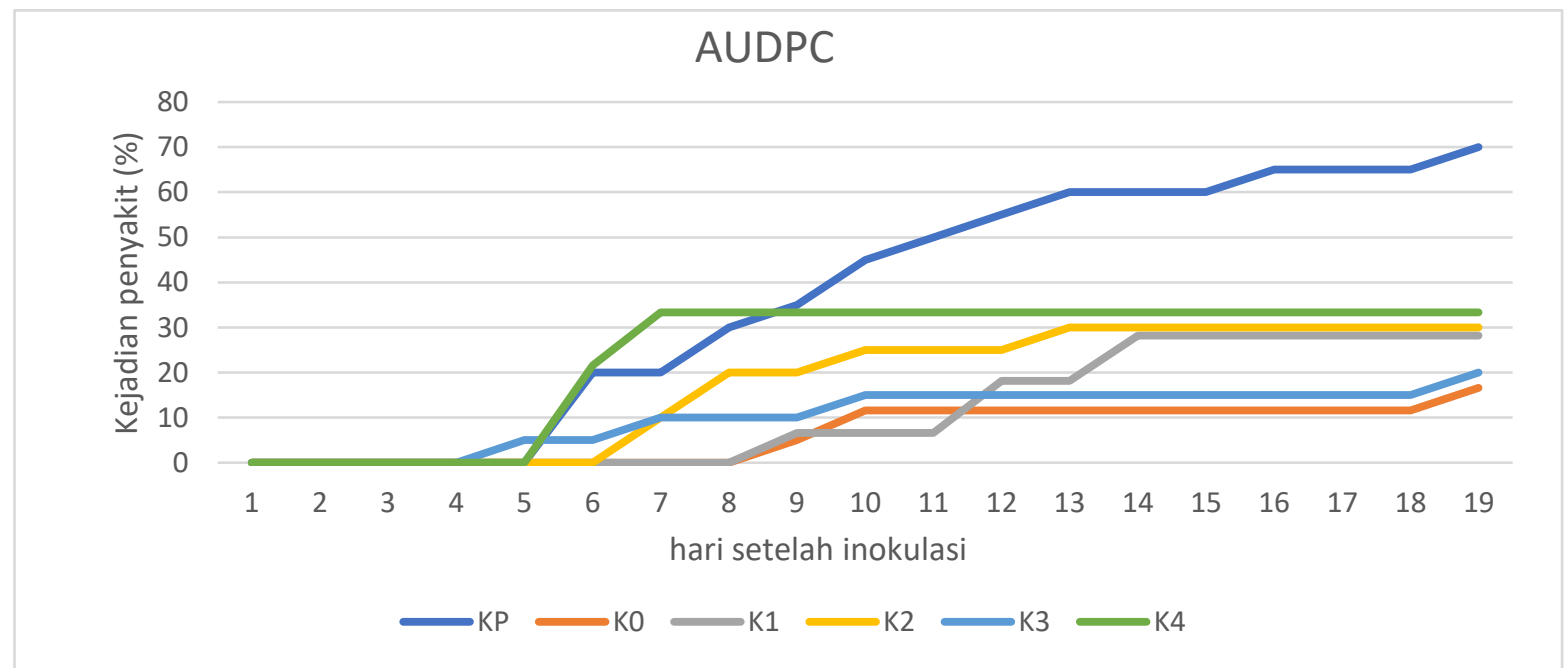

Gambar 2. Presentase kejadian penyakit rebah semai pada tanaman mentimun. Keterangan: KP = kontrol, K0 = PDB, K1-K4 = bertutur-turut tepung jagung 5, 10, 15, dan $20 \mathrm{~g} / \mathrm{L}$.

\section{Komponen Pertumbuhan}

Semakin rendah nilai AUDPC, semakin rendah pula kemampuan patogen untuk berkembang dan menimbulkan penyakit (Jeger \& Viljanen-Rollinson 2001). Angka AUDPC yang semakin rendah menunjukkan perlakuan semakin efektif dalam mengendalikan patogen, dan sebaliknya.

Potensi tumbuh maksimum dan daya kecambah 
Aplikasi metabolit sekunder tidak berpengaruh nyata terhadap daya kecambah dan potensi tumbuh maksimum benih mentimun (Tabel 2). Benih yang tidak berkecambah atau berkecambah tidak normal tidak terdapat gejala yang diakibatkan patogen Pythium sp. Perkecambahan lebih dipengaruhi oleh faktor di dalam benih itu sendiri.

Hasil pengamatan menunjukkan nilai potensi tumbuh maksimum dan daya kecambahnya tinggi. Hal ini mungkin karena benih yang ditanam memiliki kekuatan yang baik. Kekuatan yang baik didukung karena aerasi yang baik pada tanaman kontrol dan perawatan, sehingga metabolit sekunder yang diberikan tidak memiliki pengharuh nyata. Hasil ini sejalan dengan pendapat Finch-Savage \& Bassel (2016) yang menjelaskan bahwa benih yang mampu tumbuh secara normal, walaupun kondisi alam tidak optimum, disebut benih yang memiliki kekuatan yang baik.

Tabel 2. Potensi tumbuh maksimum dan daya kecambah benih mentimun

\begin{tabular}{ccc}
\hline Perlakuan & Potensi tumbuh maksimum $(\%)$ & Daya kecambah $(\%)$ \\
\hline Kontrol & $100 \mathrm{a}$ & $95 \mathrm{a}$ \\
PDB & $95 \mathrm{a}$ & $95 \mathrm{a}$ \\
Tp jagung $5 \mathrm{~g} / \mathrm{L}$ & $90 \mathrm{a}$ & $90 \mathrm{a}$ \\
Tp jagung $10 \mathrm{~g} / 1$ & $100 \mathrm{a}$ & $100 \mathrm{a}$ \\
Tp jagung $15 \mathrm{~g} / 1$ & $100 \mathrm{a}$ & $100 \mathrm{a}$ \\
Tp jagung $20 \mathrm{~g} / 1$ & $95 \mathrm{a}$ & $90 \mathrm{a}$ \\
\hline
\end{tabular}

Keterangan: Angka yang diikuti huruf sama pada kolom sama menunjukkan tidak be rbeda nyata pada BNJ dengan taraf kesalahan 5\%.

Faktor yang memengaruhi perkecambahan suatu benih, yaitu faktor dari benih itu sendiri dan faktor lingkungan. Faktor internal benih meliputi tingkat kematangan, ukuran dan dormansi, sedangkan faktor lingkungan meliputi air, suhu, udara dan cahaya (Moiwend et al. 2015). Hasil penelitian Waruwu et al. (2016) menyatakan, aplikasi metabolit sekunder jamur endofit tidak memengaruhi daya kecambah benih padi. Namun aplikasi metabolit sekunder tersebut mampu menekan tingkat infeksi Fusarium sp.

$$
\text { Hasil analisis statistika }
$$

menunjukkan perlakuan metabolit sekunder $T$. harzianum T10 tidak berpengaruh nyata terhadap tinggi tanaman, bobot tajuk, panjang akar, dan. bobot akar (Tabel 3). Bibit mentimun pada penelitian memiliki tinggi dan bobot tajuk yang hampir sama pada semua perlakuan. Hal tersebut diduga kerena faktor lingkungan sekitar pertanaman sesuai dengan yang dibutuhkan untuk pertumbuhan tanaman.
Selain dari faktor lingkungan, aplikasi metabolit sekunder $T$. harzianum $\mathrm{T} 10$ terlalu sedikit atau kurang tinggi kandungan senyawa di dalam metabolit sekunder.Tabel 3. Pertumbuhan bibit mentimun pada berbagai konsentrasi metabolit sekunder.

$$
\text { Kondisi lingkungan sekitar }
$$
pertanaman pada kondisi cahaya tinggi, $\mathrm{pH}$ tanah 6,9, drainase yang baik, dan cukup unsur hara. Tanaman mentimun terutama jenis hibrida sangat respon terhadap pemupukan. Peranan unsur hara dari pemupukan berpengaruh besar dalam meningkatkan pertumbuhan mentimun (Fefiani dan Barus 2014). Hasil ini sejalan dengan penelitian Shofiyani dan Budi (2014), yang menjelaskan bahwa pemberian pupuk organik pada awal penanaman memiliki pengaruh langsung pada ketersediaan nutrisi yang dibutuhkan oleh tanaman selama penelitian, sehingga peran agensia hayati tidak memiliki pengaruh nyata. 
Tabel 3. Pertumbuhan bibit mentimun pada berbagai konsentrasi metabolit sekunder

\begin{tabular}{ccccc}
\hline Perlakuan & $\begin{array}{c}\text { Tinggi tanaman } \\
(\mathrm{cm})\end{array}$ & $\begin{array}{c}\text { Panjang akar } \\
(\mathrm{cm})\end{array}$ & $\begin{array}{c}\text { Bobot akar } \\
(\mathrm{g})\end{array}$ & Bobot tajuk $(\mathrm{g})$ \\
\hline Kontrol & 30,70 & 15,80 & 1,39 & 17,87 \\
PDB & 32,56 & 17,01 & 1,38 & 18,63 \\
Tp jagung 5 g/L & 30,57 & 17,77 & 1,35 & 16,80 \\
Tp jagung 10 g/l & 30,29 & 16,20 & 1,37 & 16,69 \\
Tp jagung 15 g/l & 34,76 & 15,72 & 1,41 & 17,46 \\
Tp jagung 20 g/l & 32,68 & 17,56 & 1,32 & 18,38 \\
\hline
\end{tabular}

Keterangan: Data komponen pertumbuhan ditransformasi ke $\sqrt{\mathrm{x}}$.

Di samping dari pupuk, diduga hara diperoleh dari aktivitas T. harzianum dalam meyediakan hara. Trichoderma. harzianum mampu menguraikan bahan organik tanah seperti N, P, K, Al, Fe, dan Mn. Pemberian T. harzianum pada 7 hari sebelum tanam dapat menyiapkan hara tanah, sehingga pertumbuhan tanaman lebih baik (Hardianti et al. 2014).

Panjang dan bobot akar pada kontrol dan perlakuan metabolit sekunder memiliki hasil yang hampir seragam (Tabel 3). Adanya bahan organik yang melimpah dan aerasi tanah yang baik dapat mendukung pertumbuhan akar tanaman. Kondisi lingkungan yang mendukung, menyebabkan adanya patogen dan aplikasi metabolit sekunder tidak memberikan pengaruh yang nyata pada panjang dan bobot akar tanaman. Penyakit rebah semai dapat berkembang cepat pada keadaan tanah yang hangat dan basah dengan drainase yang buruk (Sutton et al. 2006). Pertumbuhan akar yang baik pada kontrol ataupun perlakuan metabolit sekunder, menyebabkan nutrisi dapat tersalurkan, sehingga pertumbuhan tanaman juga baik.

\section{KESIMPULAN}

Kepadatan konidium T. harzianum T10 tertinggi pada formula medium cair tepung jagung konsentrasi $20 \mathrm{~g} / \mathrm{L}$ sebesar $3,67 \times 10^{6}$ konidium/mL, dan belum mampu menyamai medium PDB, dengan perbandingan 1:6,5. Aplikasi metabolit sekunder T. harzianum T10 yang efektif untuk menekan penyakit rebah semai adalah metabolit sekunder T. harzianum T10 dalam formula medium cair tepung jagung konsentrasi $15 \mathrm{~g} / \mathrm{L}, \quad$ mampu menekan kejadian penyakit $71,43 \%$ dan menunda masa inkubasi 35,83\%. Aplikasi metabolit sekunder $T$. harzianum T10 dalam formula cair tepung jagung semua konsentrasi dengan kepadatan $10^{6}$ konidium $/ \mathrm{mL}$ belum mampu berpengaruh nyata terhadap komponen pertumbuhan.

\section{DAFTAR PUSTAKA}

Aini N. 2013. Teknologi Fermentasi pada Tepung Jagung. Graha Ilmu. Yogyakarta. 8-9 pp.

Akagi A, Jiang C, Takatsuji H. 2015. Magnaporthe oryzae inoculation of rice seedlings by spraying with a spore suspension. Bio-protocol 5(11):e1486.

Al-Zaidi AA, Elhag EA, Al-Otaibi SH, Baig MB. 2011. Negative effects of pesticides on the environment and the farmers awareness in Saudi Arabia: A case study. Journal of Animal and Plant Sciences, 21(3):605-611.

Borin GP, Camila Cristina Sanchez CC, de Souza AP, de Santana ES, de Souza AT, Leme AFP, Squina FM, Buckeridge M, Goldman GH, de Castro Oliveira JV. 2015. Comparative secretome analysis of Trichoderma reesei and Aspergillus niger during growth on sugarcane biomass. PLoS ONE 10(6): e0129275. 
Byrd AL, Segre JA. 2016. Adapting Koch's postulates. Science 351(6270):224226.

Ekowati N, Sucianto ET, Muljowati JS, Dewi R. 2009. Uji aktivitas antibiosis beberapa isolat Gliocladium dan Trichoderma terhadap mikrob patogen dengan $\mathrm{pH}$ awal fermentasi yang berbeda. Jurnal Inovasi 3(2): 69-77.

Fefiani Y, Barus WA. 2014. Respon pertumbuhan dan produksi tanaman mentimun (Cucumis sativus L.) akibat pemberian pupuk kandang sapi dan pupuk organik padat supernasa. Jurnal Agrium 19(1)

Finch-Savage WE, Bassel GW. 2016. Seed vigour and crop establishment: extending performance beyond adaptation. Journal of Experimental Botany 67(3): 567-591.

Ghazanfar MU, Raza M, Raza W, Qamar MI. 2018. Trichoderma as potential biocontrol agent, its exploitation in agriculture: A review. Plant Protection. 02(03): 109-135.

Gusnawaty HS, Taufik M, Syair, Esmin. 2014. Efektifitas Trichoderma indigenus hasil perbanyakan pada berbagai media dalam mengendalikan penyakit layu Fusarium dan meningkatkan pertumbuhan serta produksi tanaman tomat (Lycopersicum esculentum). Jurnal Agriplus 24 (2): 99-110.

Han JS, Cheng JH, Yoon TM, Song J, Rajkarnikar A, Kim WG, Yoo ID, Yang YY, Suh JW. 2012. Biological control agent of common scab disease by antagonistic strain Bacillus sp. sunhua. Journal of Applied Microbiology 99: 213-221.

Hardianti AR, Rahayu YS, Asri MT. 2014. Efektivitas waktupemberian Trichoderma harzianum dalam mengatasi serangan layu Fusarium pada tanaman tomat varietas Ratna. Jurnal LenteraBio 3(1): 21-25.
Heydari A, Pessarakli M. 2010. A review on biological control of fungal plant pathogens using microbial antagonists. Journal of Biological Sciences 10(4): 273-290.

HinaSaeed, AW. 2017. A review on Cucumber (Cucumis sativus). International Journal of Technical Research \& Science 2(vi): 402-405.

Hockberger P. 2000. The discovery of the damaging effect of sunlight on bacteria. Journal of Photochemistry and Photobiology B Biology 58(2-3): 185-191.

Jansch S, Frampton GK, Rombke J, Brink PJVD, Scott-Fordsmand JJ. 2006. Effects of pesticides on soil inverterbrates in model ecosystem and field studies: a review and comparison with laboratory toxicity data. Environmental Toxhicology and Chemistry. 25: 2490-2501.

Jeger MJ, Viljanen-Rollinson SLH. 2001. The use of the area under the diseaseprogress curve (AUDPC) to assess quantitative disease resistance in crop cultivars. Theoretical and Applied Genetics. 102(1): 32-40.

Lahre SK, Khare N, Lakpale N, Chaliganjewar SD. 2012. Efficacy of bio-agents and organic amendments against Sclerotium rolfsii in chickpea. Journal of Plant Disease Sciences 7 (1): 32-34.

Ling ASC, Kamil MJA, Chong KP, Ho CM. 2017. Assessing the cocoa genotypes for resistance to black pod using the area under the diseaseprogress curve (AUDPC). Bulgarian Journal of Agricultural Science 23(6): 972-997.

Manurung EM, Tobing MC, Lubis L, Priwiratama H. 2012. Efikasi beberapa formulasi Metarhizium anisopliae terhadap larva Oryctes rhinoceros L. (Coleoptera: Scarabaeidae) di insektarium. Jurnal Online Agrooekoteknologi 1(1): 4763. 
Mishra PK, Khan FN. 2015. Effect of different growth media and physical factors on biomass production of Trichoderma viride. People's Journal of Scientific Research 8(2): 11-16.

Moiwend KY, Aiyen, Madauna IS. 2015. Uji viabilitas benih ketimun (Cucumis sativus L.) hasil perlakuan penyerbukan berbagai serangga. $E$ Jurnal Agroteknis 3(2): 178-186.

Munir S, Jamal Q, Bano K, Sherwani SK, Bokhari TZ, Khan TA, Khan RA, Jabbar A, Anees M. 2013. Biocontrol ability of Trichoderma. International Journal of Agriculture and Crop Sciences 6(18): 1246-1252.

Murtiningsih, Suyanti. 2011. Membuat Tepung Umbi dan Variasi Olahannya. PT. AgroMedia Pustaka. Jakarta Selatan. 06 pp.

Muturi EJ, Donthu RK, Fields CJ, Moise IK, Kim C-H. 2017. Effect of pesticides on microbial communities in container aquatic habitats. Sci Rep. 7: 44565 .

Noordzij M, Dekker FW, Zoccali C, Jager KJ. 2010. Measures of disease frequency: Prevalence and incidence. Nephron Clin Pract 115: c17-c.

Panahian G, Rahnama K, Jafari M. 2012. Mass production of Trichoderma spp. and application. International Research Journal of Applied and Basic Sciences 3 (2): 292-298.

Patil AD, Rathore MS. 2018. Isolation of pythium species from damping off affected onion rhizospheric soil, using baiting technique. Journal of Pharmacognosy and Phytochemistry 7(4): 12-13.

Saha A, Mandala P, Dasgupta S, Saha D. 2008. Influence of culture media and environmrntal factors on mycelial growth and sporulation of Lasiodiplodia theobromae (Pat.) Griffon and Maubl. Journal of Environmental Biology 29(3): 407410.
Salman M, Abuamsha R, Barghouti S. 2013. Interaction of Fluorescent Pseudomonads with Pythium ultimum and Rhizoctonia solani in Cucumber Roots. American Journal of Experimental Agriculture, 3(1): 240-251.

Shofiyani A, Budi GP. 2014. Development of Fusarim disease control technology with biological agent in Mas cultivar banana in land infected. AGRITECH 16 (2): 157-173.

Suarni dan Firmansyah I.U. 2005. Beras Jagung; Prosessing dan Kandungan Nutrisi Sebagai Bahan Pangan Pokok. Prosiding Seminar dan Lokakarya Nasional. 393-398.

Suryanti IAP, Ramona Y, Proborini MW. 2013. Isolasi dan indentifikasi jamur penyebab penyakit layu dan antagonisnya pada tanaman kentang yang dibudidayakan di Bedugul, Bali. Jurnal Biologi (2): 37-44.

Sutton JC, Sopher CR, Owen-Going TN, Liu W, Grodzinski B, Hall JC, Benchimol RL. 2006. Etiology and epidemiology of Pythium root rot in hydroponic crops: current knowledge and perspectives. Summa Phytopathologica, 32(4): 307-321.

Tran NH. 2010. Using Trichoderma sp. for biological control of plant pathogens in Vietnam. Journal ISSAAS 16 (1): 17-21.

Vinale F, Sivasithamparam K, Ghisalberti EL, Woo SL, Nigro M, Marra R, Lombardi N, Pascale A, Ruocco M, Lanzuise S, Manganiello G, Lorito M. 2014. Trichoderma secondary metabolites active on plants and fungal pathogens. The Open Mycology Journal 8(1):127-139.

Waruwu AAS, Soekarno BPW, Munif A. 2016. Metabolit cendawan endofit tanaman padi sebagai alternatif pengendalian cendawan patogen terbawa benih padi. Jurnal Fitopatologi Indonesia 12(2): 53-61. 
